\title{
SIMILITUDE AND THERMAL PERFORMANCE ON NON-CONVENTIONAL ROOFS
}

\author{
Carlos A. de P. Sampaio ${ }^{1 *}$, Rodrigo F. Terezo², Talitha O. Rosa ${ }^{2}$, Mariana C. Burigo ${ }^{2}$, \\ Leonardo de B. Andrade ${ }^{3}$
}

${ }^{1 *}$ Corresponding author. Universidade do Estado de Santa Catarina - UDESC/ Lages - SC, Brasil.

E-mail: carlos.sampaio@cav.udesc.br

\section{KEYWORDS building, scale, environmental factors.}

non-conventional roofs, The objectives of this study were to evaluate the thermal comfort and the similitude and expanded clay aggregate, supported on wood frame structure. For this, were determined the Black Globe Temperature and Humidity Index (BGHI), the Human Discomfort Index (HDI), Effective Temperature (ET), Air Temperature (Tair) and Radiant Thermal Load (RTL), from March 2013 to December 2014. The results showed that there were no statistical differences to $5 \%$ significance in predicting heat indices between the prototypes and models. Observing all indexes simultaneously, it was observed that January was the month what led to the worst heat conditions, while June and July showed the worst cold conditions. It can be concluded that the use of reduced models is possible $(1: 2)$ compared to the prototype (1:1), with green roofs and expanded clay as covering element, for the prediction of thermal indexes, minimizing construction costs and use of spaces.

\section{INTRODUCTION}

In tropical regions there is almost constant occurrence of temperatures above the thermo neutral environment of humans and animals, consequently this causes an increase in energy demand for air cooling besides environmental impacts for its generation.

The roof is one of the constructive components with the greatest influence on the conditions of the internal environment of a building (Cardoso et al., 2011). According to Baêta \& Souza (2010), the use of shelters with suitable roof's materials can promote a reduction of up to $30 \%$ of the radiant thermal load.

The building high cost on a natural scale for the knowledge of new technologies often makes research impossible to be conducted. In this sense, the use of reduced models allows to test several configurations in a more agile way, with reduction of the constructive costs and space. This is a widely used tool in engineering, but its application requires that reduced models and prototypes behave significantly equal.

Green roofs have been evaluated in various conditions around the world, indicating that this technology adds layers of insulation, slows the flow of heat through the vegetation cover, helps in reducing the heat islands in urban areas (Terezo et al., 2014), reduces rainwater runoff (Tassi et al., 2014; Santos et al., 2013) and even provides a reduction of air pollution (Gartland, 2010).

Spolek (2008) reports that green roofs show a high decrease in heat transfer compared to conventional roofs, whose conclusion was made after a short study. However, Pérez et al. (2015) comment on the need for greater observation time regarding the use of this technique.

Expanded clay is a ceramic material with potential for thermal insulation, presents low density and is formed by an alveolar core produced by the burning of natural clay at high temperatures. It is most commonly used in lightweight concrete walls as reported by Sacht et al. (2010), however its use to increase thermal inertia in roofs is almost non-existent.

The importance of human and animal thermal comfort are shown on studies, among them those made by Carneiro et al. (2015), Fagianelli et al. (2014); Santos et al. (2014); Tassi et al. (2014); Jentzsch et al. (2013), Melo et al. (2013), and Passini et al. (2013).

By the exposed, the objective of this study was to evaluate the thermal comfort between prototypes in scale models and reduced size, using vegetation cover and expanded clay as an increase in thermal inertia, as well as

${ }^{2}$ Universidade do Estado de Santa Catarina - UDESC/ Lages - SC, Brasil.

${ }^{3}$ Universidade Federal de Santa Catarina - UFSC/ Florianópolis - SC, Brasil.

Received in: 5-25-2017

Accepted in: 11-9-2017 
to verify the similitude between the buildings in the indication of thermal comfort and air temperature indexes.

\section{MATERIAL AND METHODS}

This study was carried out in the Construction and Ambience Area of the Center of Agroveterinary Sciences (CAV) of the Santa Catarina State University (UDESC) in the city of Lages/SC, which has the following geographic coordinates: latitude $27^{\circ} 49^{\prime}$ South, longitude of $50^{\circ} 20^{\prime}$ West and altitude of $940 \mathrm{~m}$. The predominant climate of the region, according to the KÖPPEN classification is $\mathrm{Cfb}$ (mesothermic constantly humid with mild summer), with rainy periods mainly in the summer. Its location is surrounded by plateaus, with moderate and predominant winds in the northeast direction.

The region has two well defined seasons, one with a mild to warm summer between November and March, characterized by well distributed rainfall, average relative humidity of $77 \%$ and average maximum temperature of $25.1^{\circ} \mathrm{C}$, and another one cold in the winter between May and August, prevailing cold winds, certain frequency rains, average relative humidity of $82 \%$ and average minimum temperature of $7.7^{\circ} \mathrm{C}$.

In order to compare the coverages and the similitude criteria, two prototypes were constructed in natural scale (1:1) and two models in reduction scale (1:2),
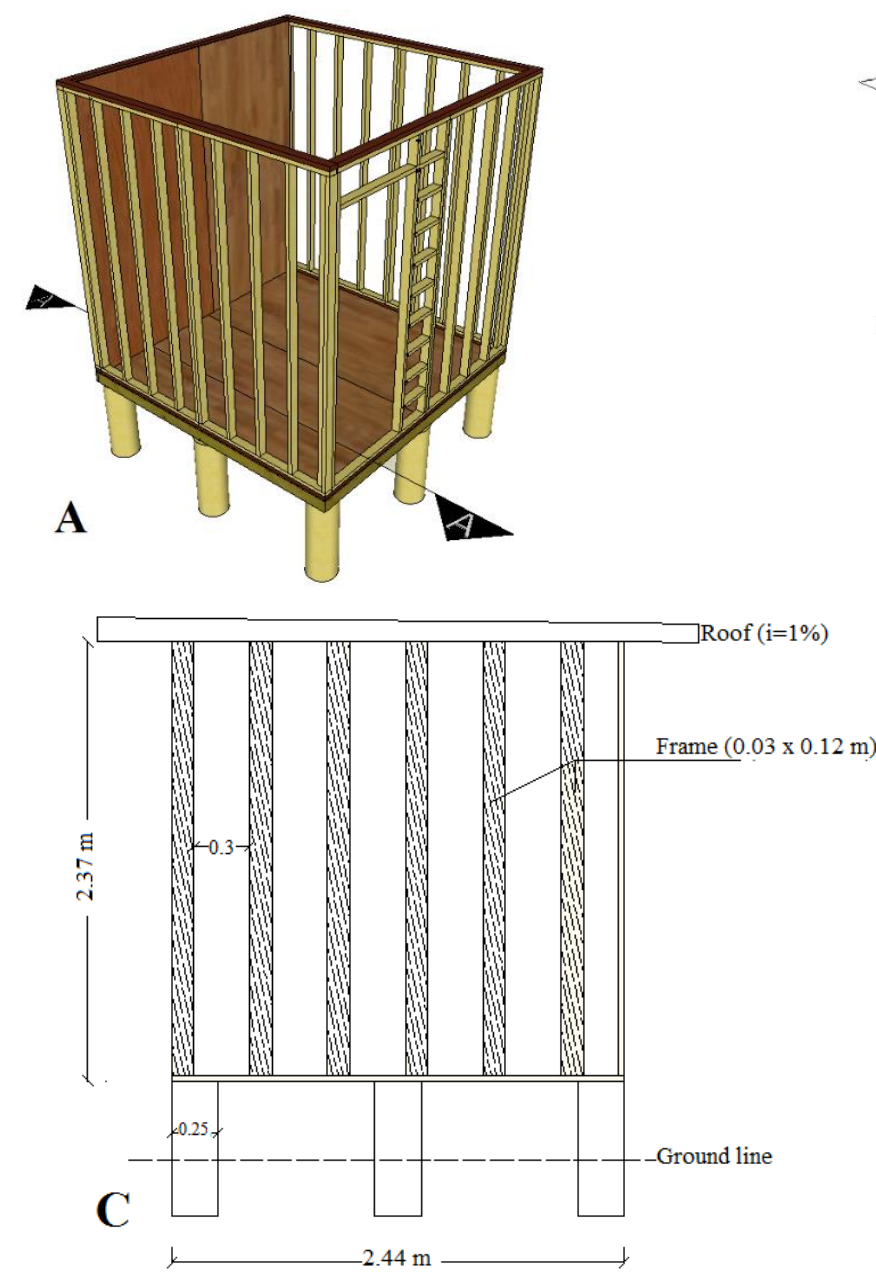

FIGURE 1. Drawings of the prototype in natural scale and the model in reduction scale: perspective drawing of the prototype (A); quoted drawing in perspective of the prototype (B); cross-section of the prototype (C) and cross-section of the reduced model (D).

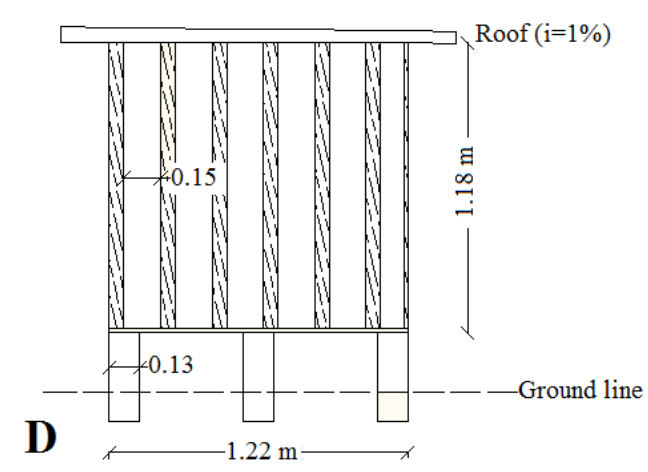

geometrically similar model class (Murphy, 1950), supported in Wood Frame structure.

According to the SINAT Directive 005 (Ministry of Cities - National Secretariat of Housing, 2011), the Wood Frame System has as main characteristic to be structured by pieces of solid cut lumber, denominated frames and closings in thin plates, providing structural support for the coverage, producing a quick and lightweight construction system.

The dimensions of the prototype were of the order of $2.44 \mathrm{~m}$ for width and length $\left(5.95 \mathrm{~m}^{2}\right.$ of exposed roof) and $2.37 \mathrm{~m}$ of height. The dimensions of the reduced model were of the order of $1.22 \mathrm{~m}$ for width and length (1.48 $\mathrm{m}^{2}$ of exposed roof, corresponding $1 / 4$ of the prototype) and height of $1.18 \mathrm{~m}$, as shown in figure $1 \mathrm{C}$ and $1 \mathrm{D}$ respectively.

In the manufacture of the walls, floors and openings, panels of $15 \mathrm{~mm}$ thick of plywood and cut lumber with dimensions of $30 \times 120 \mathrm{~mm}$ were used, which were painted in frosted white to avoid absorption of rainwater and increase durability.

At the substructure, six logs of treated Eucalyptus $s p$, with $0.25 \mathrm{~m}$ in diameter and $0.73 \mathrm{~m}$ in height were used, which were buried in the ground and concreted their base, in order to support the lower beams and to maintain the prototypes and models at $0.30 \mathrm{~m}$ above ground level.

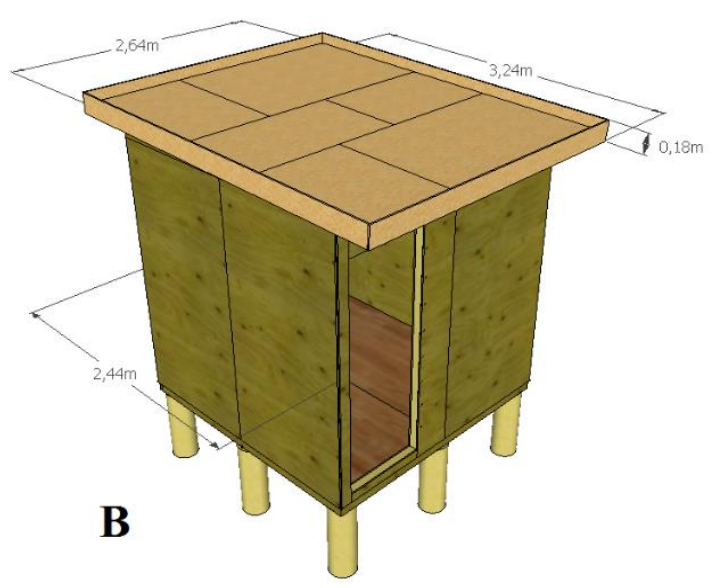

D

Engenharia Agrícola, Jaboticabal, v.38, n.1, p.7-12, jan./feb. 2018 
The roofs of the prototypes and of the models were constituted of expanded clay and vegetation and configured according to the following description: Prototype with coverage of expanded Clay (PC); Prototype with Vegetation cover (PV); Model with expanded Clay cover (MC) and Model with Vegetation cover (MV). The inclination of the roofs of both prototypes and the models was of $1 \%$, oriented in $7^{\circ}$ in the transversal direction, aiming at the maximum incidence of the solar rays on the roofs.

The vegetated cover was composed of the following layers: in the first one was used a black plastic canvas of $15 \mu \mathrm{m}$ thickness; in the second geotextile blanket of bidim type; and in the third substrate of soil with humus enclosed in tray with bottom of PET bottle, whose purpose was to contain the substrate and the last layer, by plant seedlings. These were chosen according to the following criteria: species with high resistance to water stress and high relative humidity, low maintenance, easy of acquisition and market availability, opting for grasses ("evergreen-grass").

In the preparation of the coverage with expanded clay, a $15 \mu \mathrm{m}$ black plastic canvas was used in the first layer, followed by expanded clay of varied granulometry (average of $20 \mathrm{~mm}$ in diameter), forming a lining with a thickness of $0.06 \mathrm{~m}$.

The data were collected from March / 2013 to December / 2014, only on days with solar insolation, and the data were collected at intervals from 9 am to $6 \mathrm{pm}$ in the internal and external environment of the buildings. There was no air circulation inside the prototypes and models, as the entrance door remained closed during the period of registration of the measures of interest.
The data of air temperature and black globe temperature as well as air humidity were obtained with digital black globe thermometer (Instrutemp ${ }^{\circledR}$ model ITWTG 2000), whose variables were used to determine the thermal indicators.

The thermal parameters evaluated were: the Black Globe and Humidity Index BGHI $=\mathrm{Tg}+\mathbf{0 . 3 6}$ Tdep $+\mathbf{4 1 . 5}$ (BUFFINGTON et al., 1981); the Effective Temperature $\mathrm{ET}=\mathbf{0 . 4}(\mathrm{Td}+\mathrm{Tw})+\mathbf{4 . 8}(\mathrm{THOM}, 1958)$; the Human Discomfort Index

HDI $=0.99 \mathrm{Td}+\mathbf{0 . 3 6} \mathrm{Tdep}+\mathbf{4 1 . 5}$ (ONO

\&

KAWAMURA, 1991); Radiation Thermal Load RTL $=5.67 .10^{-8} \times\{100 \cdot[2.51 \cdot(\sqrt{V}) \cdot(\mathrm{Tg}-\mathrm{Tdb})+$ $\left.\left.(\mathrm{Tg} / \mathbf{1 0 0})^{4}\right]^{0.25}\right\}^{4} \quad($ ESMAY, 1982$)$

In order to compare the thermal indexes, the design was completely randomized, with the repetitions being hourly measurements. The analysis of variance (ANOVA) was used by the F test and Tukey's test at 5\% probability to compare the means using the Sisvar ${ }^{\circledR}$ software. The readings were stored in a database referring to the green roof, expanded clay and the external environment, the latter considered the control.

\section{RESULTS AND DISCUSSION}

The averages' test for the evaluated thermal indexes and air temperature is shown in Table 1.

TABLE 1. Average values of Human Discomfort Index (HDI); Black Globe Temperature and Humidity Index (BGHI); Effective Temperature (ET), Air Temperature (Tair) and Radiation Thermal Load (RTL) for prototypes and models with green roof and expanded clay roofs.

\begin{tabular}{cccccc}
\hline & HDI & BGHI & ET & Tair & RTL \\
\hline PV & $67,90 \pm 6,45 \mathrm{~b}$ & $70,40 \pm 7,34 \mathrm{~b}$ & $19,69 \pm 4,33 \mathrm{~b}$ & $20,86 \pm 5,01 \mathrm{~b}$ & $438,26 \pm 6,55 \mathrm{a}$ \\
MV & $67,19 \pm 6,17 \mathrm{ab}$ & $69,96 \pm 7,05 \mathrm{~b}$ & $19,23 \pm 4,10 \mathrm{ab}$ & $20,63 \pm 4,83 \mathrm{ab}$ & $436,38 \pm 6,26 \mathrm{a}$ \\
PC & $67,94 \pm 6,45 \mathrm{~b}$ & $70,55 \pm 7,39 \mathrm{~b}$ & $19,72 \pm 4,36 \mathrm{~b}$ & $20,84 \pm 5,01 \mathrm{~b}$ & $437,62 \pm 6,56 \mathrm{a}$ \\
MC & $67,14 \pm 6,22 \mathrm{ab}$ & $70,03 \pm 7,07 \mathrm{~b}$ & $19,29 \pm 4,14 \mathrm{ab}$ & $20,37 \pm 4,85 \mathrm{ab}$ & $436,63 \pm 6,26 \mathrm{a}$ \\
EE & $66,42 \pm 6,06 \mathrm{a}$ & $68,64 \pm 6,50 \mathrm{a}$ & $18,73 \pm 4,00 \mathrm{a}$ & $20,01 \pm 4,77 \mathrm{a}$ & $430,25 \pm 5,75 \mathrm{~b}$ \\
CV $(\boldsymbol{\%})$ & 9,31 & 10,12 & 21,68 & 24,80 & 7,78 \\
\hline
\end{tabular}

Means followed by the same letter in the columns do not differ from each other by the Tukey test at 5\% probability. PC - prototype with expanded clay coverage; PV - prototype with vegetation coverage; MC - model with expanded clay coverage; MV - model with vegetation coverage; EE - external environment; CV - Coefficient of Variance.

Regarding the BGHI, considering that between 74 and 77 indicates a comfort condition, below 74 indicates cold stress and above 77 a heat stress, it can be seen from Table 1 that the averages of the external environment presented statistical differences in relation to the prototypes or models. It is still noticeable that the average of all treatments for BGHI presents cold stress, but presented less marked thermal sensations than those found in the external environment.

Regarding the ET, between 18.9 and $25.6^{\circ} \mathrm{C}$ is suggested a zone of thermal comfort, and the human body (adult people dressed at rest and with a slight movement of the air) presents conditions of stress to the cold and the heat under ET below the minimum and above the maximum, respectively (Thom, 1958). The prototypes and the models averages found showed thermal comfort sensations, while in the external environment, the condition of discomfort.
Regarding the HDI, it was observed that the average values of the treatments showed the desired values of the thermal comfort sensation, since the HDI ranges related to the thermal comfort conditions felt by the people are: HDI $>80$ (heat stress), HDI <55 (cold stress), $60<$ HDI $<75$ (comfortable) (Ono \& Kawamura, 1991).

The mean values Tair were for $\mathrm{PV}=20.86^{\circ} \mathrm{C}$; MV $=20.63 ; \mathrm{PC}=20.84^{\circ} \mathrm{C}$ and $\mathrm{MC}=20.37^{\circ} \mathrm{C}$, while in the external environment it was $20.01^{\circ} \mathrm{C}$, differences of 0.85 ; 0.62 ; 0.83 ; and $0.36{ }^{\circ} \mathrm{C}$, respectively. It can be considered low, this fact can be explained by the absence of air currents within the prototypes and models, that is, the heat exchanges with the environment become slower.

Figure 2 shows the comfort zones and mean variations of BGHI, ET, HDI and RTL in each month over the study period. 

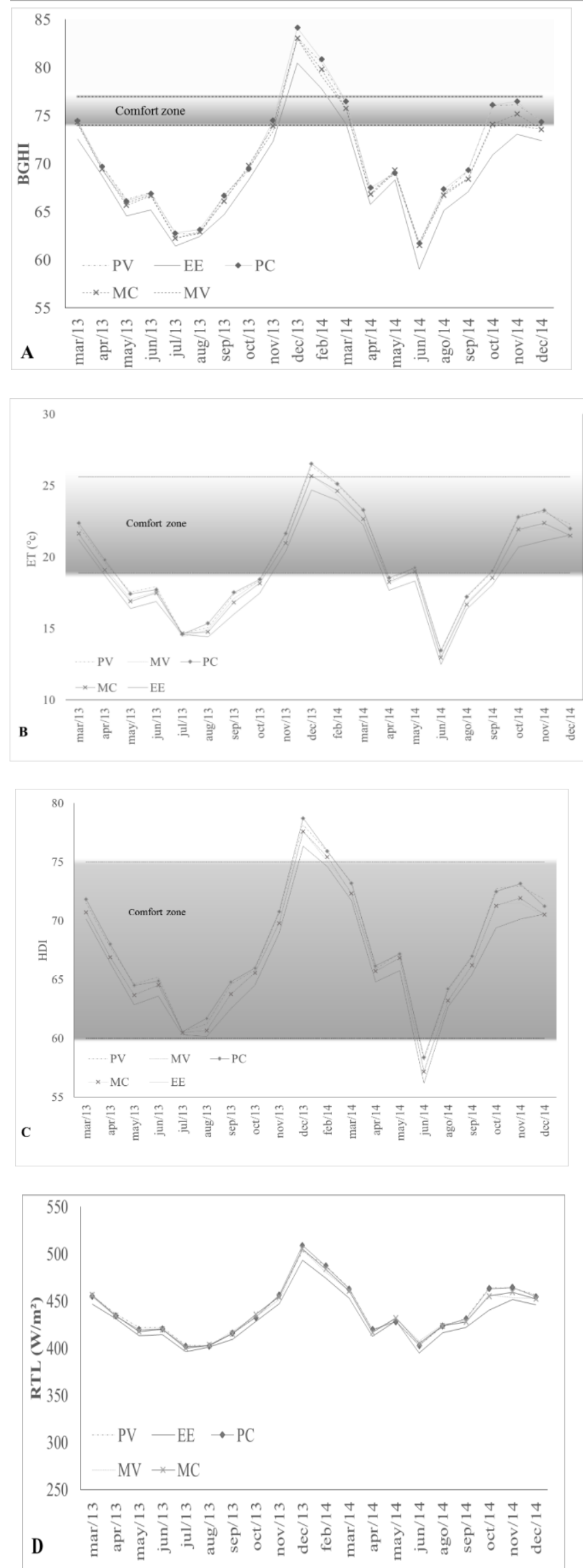

FIGURE 2. Average values of the thermal indices evaluated in each month over the study period: Black Globe Temperature and Humidity Index - BGHI (A); Effective Temperature - ET (B); Human Discomfort Index - HDI (C) and Radiation Thermal Load - RTL (D).
As for the BGHI, it is observed that in the majority of the time, the coverages did not provide thermal comfort due to heat and cold. It emphasizes the occurrence of thermal delay for cooling in the prototypes due to the greater amount of mass inside, that is, prototypes and models maintains the same tendency of temperatures, as well as the sensitivity of the index in front of the others in the indication of thermal discomfort.

Carneiro et al. (2015) in the period from March/14 to May/14 obtained higher rates for BGHI in the conditions of predominant megathermic climate (As'), with average values of BGHI for the green roofs of 78 .

Cardoso et al. (2011) evaluating the roofing conditions made with alternative materials (aluminized reciplac and Tetra Pak recycle) compared to clay roofing under hot conditions and with the use of similitude theory, it was generally observed that there was similarity between the results. They concluded that in the hottest period of the day, the best conditions were associated with the mud cover.

It is also possible to observe in the BGHI chart the difference between observed and the required value for thermal comfort. This is due to the concept of "black body radiation", in which every body emits and absorbs radiation at ambient temperatures, that is, the lower the body temperature the smaller the amount of radiation it emits. In addition, the temperatures in the winter months are lower; this affects the amount of radiation that the black globe captures, reducing the thermal comfort inside the buildings. This is due to the long wave of radiation emitted by the green roofs, which is inferior to the one emitted by the conventional opaque surfaces, that is, as the vegetated surfaces absorb part of the solar radiation, they make difficult the passage of this one to the inferior surfaces, diminishing the elevation of the temperature in the cold months (Baêta \& Souza, 2010).

The ET values suggest a situation of thermal comfort due to heat, especially in the hottest months. In the cold months, cold stress conditions are noted, with temperatures below $18.9^{\circ} \mathrm{C}$. This index is widely used in the identification of heat islands in cities and human discomfort (Santos Júnior et al., 2016; Peixoto et al., 2012).

For the HDI, it was observed that, in the great majority of the time, there was thermal comfort in the prototypes and models, however only in the extreme conditions of heat and cold, it was observed conditions of stress.

Santos et al. (2014) measuring the HDI in the rainy and dry season, between May 2008 and May 2011, in Arapiraca - Alagoas (hot and humid tropical climate with temperatures varying between 17 and $28^{\circ} \mathrm{C}$ ), obtained values of $75-80$, stress condition at heat. This study shows the tendency of human discomfort with increasing air temperature.

Oliveira Júnior et al. (2015) describe that the discomfort index can be applied in thermal comfort assessments, more common in human work environments, but can be applied in animal production facilities, in which the parameters must be adjusted according to the animal to be evaluated.

For the RTL values, very close conditions between prototypes and models could be verify, with low coefficient of variation. For all the indexes, it was the only that presented the lowest variability, showing that the thermal inertia of the roofs was similar. 
Silva et al. (2015) evaluating the thermal performance of roofs (ceramic tile, aluminum tile and asphalt fiber) in reduced models $(1: 10)$ directed to poultry houses, found a mean RTL of 453.09, 459.39 and 457.86 $\mathrm{W} . \mathrm{m}^{-2}$ for ceramic tile, aluminum tile and asphalt vegetal fiber tile, respectively, that is, an average variation of only $6.3 \mathrm{~W} \cdot \mathrm{m}^{-2}$.

Castro et al. (2017) evaluating the use of different cover combinations (ceramic tiles and white painted fiber cement, associated with polypropylene linings and thermoreflective fabric) in reduced models of animal production facilities based on thermal comfort indexes. They were verified that the maximum radiation's thermal loud occurred near at $2 \mathrm{pm}\left(515.36\right.$ to $\left.573.36 \mathrm{~W} . \mathrm{m}^{-2}\right)$, being the best treatment formed by fiber-cement tile with specific polypropylene lining under cover. The worst treatment was formed by fiber-cement tile with thermo-reflective screen on the tiles $\left(544.05 \mathrm{~W} \cdot \mathrm{m}^{-2}\right)$.

As for similitude and directed to the indexes evaluated, the relationship between prototypes and models remained statistically the same for the reduction scale 1:2. This is an applicable concept for modeling trials in engineering, that is, a model is said to have similitude to the actual application, if the two share geometric, kinematics and dynamics similitude.

Similar results were obtained by Jentzsch et al. (2013), who analyzing all variables together did not find significant differences between the measurements of the prototype with the reduced model, commenting further that these thermal variations during a day in the prototypes did not vary until the reduction of 1:2 for the model. The same author, analyzing different reduction scales for models with asbestos cement coverage on 10 days of summer, found that all BGHI values were favorable to thermal comfort, indicating that there are no differences between BGHI among models and prototypes when the coverage used is the same in both buildings.

\section{CONCLUSIONS}

The prototypes in the natural scale $1: 1$ and reduced models in the 1:2 scale showed similitude for the thermal comfort indexes evaluated, presenting no statistical differences between them. The BGHI was the one that showed the greatest rigor in the indication of thermal comfort, covering a small range, while the ET presented an intermediate condition of thermal comfort. The roofs provided conditions of thermal comfort in a wider range measured by the HDI, except in the extreme months of temperatures. The RTL showed similar behavior between prototypes and models, with low coefficient of variation. The incidence of solar radiation in the coverage led to an increase in the internal air temperature (Tair) and this mass of hot air not being dissipated by the wind currents provided the thermal increase in the prototypes and models. Observing all the indexes simultaneously, it is noticed that the month of January was the one that gave the worse conditions against the heat, where as the months of June and July presented the worse conditions against the cold.

\section{REFERENCES}

Baêta FC, Souza CF (2010) Ambiência em edificações rurais: conforto animal. Viçosa, UFV. 269 p.
Buffington DE, Collazo-Arocho A, Canton GH, Pitt D (1981) Black globe humidity index (BGHI) as comfort equation for dairy cows. Transactions of the ASAE 24(3):711-714.

Cardoso AS, Baêta FC, Tinoco IFF, Cardoso VAS (2011) Coberturas com materiais alternativos de instalações de produção animal com vistas ao conforto térmico. Engenharia na Agricultura 19(5):404-421.

Carneiro TA, Guiselini C, Pandorfi H, Lopes Neto JP, Loges V, Souza RFL (2015) Condicionamento térmico primário de instalações rurais por meio de diferentes tipos de cobertura. Revista Brasileira de Engenharia Agrícola e Ambiental 19(11):1086-192.

Castro, AC, Silva IJO, Nazareno AC, Nunes MLA, Piedade SMS (2017) Thermal efficiency of different coverage materials in reduced models of animal husbandry facilities: a case study. Revista Engenharia Agrícola 37(3):403-413.

Esmay ML (1982) Principlesof animal environment. Westport, Avi Publishing. 325p.

Fagianelli GA, Brun A, Wurtz E, Musseli M (2014) Natural cross ventilation in buildings on Mediterranean coastal zones. Energy and Building 77:206-218.

Gartland L (2010) Ilhas de calor: como mitigar zonas de calor em áreas urbanas. São Paulo, Oficina de Textos. $243 p$.

Jentzsch R, Baeta F da C, Tinôco I de F F, Damasceno FA, Saraz JAO (2013) Parâmetros arquitetônico-ambientais para construção e testes em modelos reduzidos, representativos de galpões avícolas com base em similitude. Engenharia da Agricultura 21(1):19-30.

Melo T, Furlan R, Milani A, Buzanskas M, Moura A, Mota D, Cardoso D (2013) Avaliação de diferentes inclinações e exposições de telhado em três tipos de cobertura em modelos reduzidos de instalações zootécnicas. Semina: Ciências Agrárias 34(3):1327-1338.

SINAT - Sistema Nacional de Avaliações técnicas (2011) Sistemas construtivos estruturados em peças de madeira maciça serrada, com fechamentos em chapas delgadas (Sistemas leves tipo "Light Wood Framing”). Brasília, DF (Diretriz SINAT $n^{\circ}$ 005). Available: http://pbqph.cidades.gov.br/projetos_sinat.php. Accessed Jun 21, 2016.

Murphy GCE (1950) Similitude in engineering. New York, Ronal Press. 302p.

Oliveira Júnior AJ, Souza SRL, Barros ZX, Sartori MMP, Franco LV (2015) Índice de desconforto e índice de temperatura efetiva: uma implementação para smartphones e tablets. Revista Energia na Agricultura 30(2):155-163.

Ono HSP, Kawamura T (1991) Sensible climates in Monsoon Asia. Internacional Journal of Biometeorology 39(25):39-47. 
Passini R, Araujo MAG, Yasuda VM, Almeida EA (2013) Intervenção ambiental na cobertura e ventilação artificial sobre índices de conforto para aves de corte. Revista Brasileira de Engenharia Agrícola e Ambiental 17(3):333338.

Peixoto FS, Sales MCL (2012) Análise de microclimas na cidade de Viçosa do Ceará: abordagem na perspectiva do conforto térmico. Revista Brasileira de Geografia Física $5(1): 47-58$.

Pérez G, Vila A, Solé C, Coma J, Castell A, Cobeza LF (2015)The thermal behavior of extensive green roofs under low plant coverage conditions. Energy Efficiency 8:881894.

Sacht HM, Rossignolo JÁ, Santos NN (2010) Avaliação da condutibilidade térmica de concretos leves com argila expandida. Revista Matéria 15(1). DOI:http://dx.doi.org/10.1590/S151770762010000100005

Santos Júnior JB, Castro LMSP, Alves ER, Sales MCL (2016) Microclimas do município de Viçosa do Ceará: uso da temperatura efetiva na análise do conforto térmico. Revista de Geociências do Nordeste (2). Número especial.

Santos JB, Amorim RFC, Cavalcante LPA (2014) Análise do conforto térmico humano no município de Arapiraca Alagoas, utilizando software MATLAB. Revista Brasileira de Geografia Física 7(5): 939-948.
Santos PTS, Santos SM dos, Montenegro SMGL, Coutinho AP, Moura GSS de, Antonino ACD (2013) Telhado verde: desempenho do sistema construtivo na redução do escoamento superficial. Ambiente Construído13(1):161-174.

Silva MG, Martin S, Oliveira CEG, Moscon ES, Damasceno FA (2015) Desempenho térmico de tipos de coberturas no interior de modelos reduzidos de galpões avícolas. Energiana Agricultura 30(3):269-275.

Spolek G (2008) Performance monitoring of three ecoroofs in Portland, Oregon. Urban Ecosystems 11:349359.

Tassi R, Tassinari LCS, Piccilli DGA, Persch CG (2014) Telhado verde: uma alternativa sustentável para a gestão das águas pluviais. Ambiente Construído 14(1):139-154.

Terezo RF, Rosa TO, Sampaio CA de P, Andrade LB (2014) Análise de desempenho térmico e higroscópico de três modelos de telhados. In: Congresso Luso-Brasileiro de Materiais de Construção Sustentáveis. Guimarães, Centro de Território, Ambiente e Construção Escola de Engenharia da Universidade do Minho, Campus de Azurém, Anais...

Thom EC (1958) Cooling degree - day air conditioning, heating and ventilating. Transactions of the ASAE 55(7): p.65-72. 